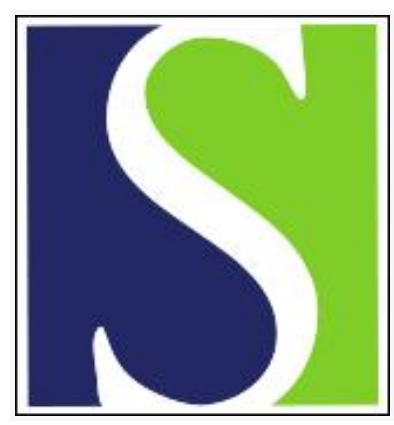

Scand J Work Environ Health 1982;8(2):129-133

https://doi.org/10.5271/sjweh.2485

Issue date: Jun 1982

Mercury in urine - sex, age and geographic differences in a reference population.

by Lie A, Gundersen N, Korsgaard KJ

Key terms: age; gender; geographic difference; mercury; normal value; reference population; sex; urinary mercury; urine

This article in PubMed: www.ncbi.nlm.nih.gov/pubmed/7134930

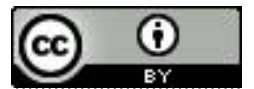




\title{
Mercury in urine - Sex, age and geographic differences in a reference population
}

\author{
by Arve Lie, MD, ${ }^{1}$ Nils Gundersen, MSc, ${ }^{1}$ Karl J Korsgaard, MD²
}

\begin{abstract}
LIE A, GUNDERSEN N, KORSGAARD KJ. Mercury in urine - Sex, age and geographic differences in a reference population. Scand $j$ work environ health 8 (1982) 129-133. The urine of 103 inhabitants from Hadeland and 240 persons from Odda, Norway, was examined with respect to the content of mercury and creatinine. Odda is a small community in a narrow fiord on the western coast of Norway. The sea water is polluted with mercury and other heavy metals emitted from a zinc smelter. Hadeland is a less industrialized county in the eastern part of Norway without any known inorganic mercury contamination of the external environment. None of the participants of the study were occupationally exposed to mercury. The mercury excretion was significantly higher among people living in Odda and highest among those living close to the zinc smelter. This finding probably reflects a contamination of the external environment. Women in Odda and Hadeland had a higher mercury excretion than the males of the respective regions. Mercury excretion also seemed to be agedependent in that there was a gradual reduction in mercury excretion with advancing age. Although there seem to be age- and sex-dependent differences with respect to mercury excretion, $100 \mathrm{nmol}$ of mercury/l of urine and $10 \mathrm{nmol}$ of mercury/mmol of creatinine are suggested as upper limits for "normal" mercury excretion among nonoccupationally exposed persons living in Norway.
\end{abstract}

Key terms: urinary mercury normal values.

The monitoring of mercury content in urine specimens is an important tool in the surveillance of workers exposed to inorganic mercury. Previous investigations of mercury in urine in a reference population without any occupational exposure to mercury have shown that urinary mercury, as a rule, will be below $10 \mathrm{nmol} / 1$ $(3,10)$. Geographic differences and large individual differences have been found (3). These differences may be due to a "natural" release of mercury from the earth, contamination of food, and mercury release from the combustion of fossile fuels (13). In 1980 the World Health Organization suggested that $250 \mathrm{nmol}$ of mercury in urine per gram of creatinine should be regarded as an upper individual limit for mercury-exposed workers (14). This value

1 Institute of Occupational Health, Oslo, Norway.

2 Norzink A/S, Odda, Norway.

Request for reprints to: $\mathrm{Dr}$ A Lie, Institute of Occupational Health, PO Box 8149 Dep, Oslo 1, Norway. corresponds to approximately $250 \mathrm{nmol}$ of mercury per liter of urine in normally concentrated urine specimens.

Previous investigations have revealed a higher urinary mercury level among women than men (5) and a gradual reduction of urinary mercury with advancing age $(4,5)$. Besides establishing a reference material, we therefore wanted to look for possible differences in urinary mercury between geographic regions, different sexes, and different age groups.

\section{Subjects and methods}

Two different geographic regions in Norway were chosen. One, Odda, is a small but heavily industrialized community at the end of a fiord on the western coast of Norway. Throughout the last 50 a there has been a considerable output of mercury from a zinc smelter in the area. A higher than normal content of mercury in the sea water and in the fish of the fiord has been found. During the last 7 a mercury 
output from the zinc smelter has decreased considerably. From this region 240 persons participated in the study: 31 families with 113 family members living close to the zinc smelter (regions $\mathrm{A}, \mathrm{B}$ and $\mathrm{C}$ in fig 1), 82 persons working at the zinc smelter without any occupational exposure to mercury, and a group of 30 teachers and 15 students living in the center of Odda (region D in fig 1).

Hadeland, a less industrialized inland county in the eastern part of Norway was

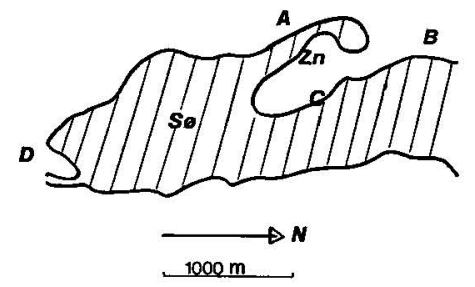

Fig 1. Map of Odda. The letters $A, B$ and $C$ refer to residences close to the zinc smelter $(\mathrm{Zn})$; region $\mathrm{D}$ indicates the center of Odda. The fiord is marked with Sø. the other region chosen. In this area there is no known pollution from inorganic mercury. From this region 103 persons working in a glass production plant were chosen.

One morning spot sample of urine was collected from each of the participants. The mercury content of the urine specimens was measured by means of flameless atomic absorption (1). The precision of the method used has been reported elsewhere (12). The coefficients of variation at the concentration levels of 70 and $20 \mathrm{nmol}$ of mercury per liter of urine were 4.7 and $7.4 \%$, respectively. Creatinine was used to adjust for concentration differences in the urinary mercury. Mercury excretion is considerably influenced by diurnal variation $(6,7)$. Diurnal sampling of urine is impractical, but creatinineadjusted urinary mercury corresponds well to the diurnal excretion of mercury $(11,12)$.

The data processing was carried out at the University of Oslo with the use of the discrete data program package.

Table 1. Urinary mercury unadjusted $(\mathrm{U}-\mathrm{Hg})$ and adjusted $(\mathrm{Hg} / \mathrm{CR})$ in Odda.

\begin{tabular}{|c|c|c|c|c|c|c|c|c|c|c|}
\hline \multirow{2}{*}{ Region a } & \multicolumn{2}{|c|}{ Number } & \multicolumn{3}{|c|}{$\mathrm{U}-\mathrm{Hg}(\mathrm{nmol} / \mathrm{l})$} & \multicolumn{3}{|c|}{$\mathrm{Hg} / \mathrm{CR}(\mathrm{nmol} / \mathrm{mmol})$} & \multicolumn{2}{|c|}{ Age (a) } \\
\hline & Men & Women & Mean & Median & Range & Mean & Median & Range & Mean & Range \\
\hline A & 20 & 17 & 54 & 33 & $5-210$ & 4.9 & 3.1 & $0.8-24.0$ & 22.3 & $4-46$ \\
\hline B & 35 & 24 & 37 & 25 & $6-149$ & 3.2 & 2.3 & $0.2-1$ & 26.1 & $3-62$ \\
\hline C & 8 & 9 & 53 & 38 & $4-198$ & 4.8 & 4.2 & $1.3-11.0$ & 24.5 & $6-41$ \\
\hline D & 21 & 24 & 28 & 23 & $6-151$ & 2.1 & 1.8 & $0.4-8.9$ & 31.1 & $10-58$ \\
\hline
\end{tabular}

a See fig 1.

b Statistics (Mann-Whitney test): U-Hg for $A+B+C / D: p<0.05 ; U-H g$ for $A+C / B$ : not significant; $\mathrm{Hg} / \mathrm{CR}$ for $\mathrm{A}+\mathrm{B}+\mathrm{C} / \mathrm{D}: \mathrm{p}<0.001 ; \mathrm{Hg} / \mathrm{CR}$ for $\mathrm{A}+\mathrm{C} / \mathrm{B}: \mathrm{p}<0.05$.

Table 2. Unadjusted $(\mathrm{U}-\mathrm{Hg})$ and creatinine-adjusted $(\mathrm{Hg} / \mathrm{CR})$ urinary mercury in the total material.a

\begin{tabular}{|c|c|c|c|c|c|c|c|c|c|c|}
\hline \multirow{2}{*}{\multicolumn{2}{|c|}{ Region }} & \multirow{2}{*}{ Number } & \multicolumn{3}{|c|}{ U-Hg $(\mathrm{nmol} / \mathrm{l})$} & \multicolumn{3}{|c|}{$\mathrm{Hg} / \mathrm{CR}(\mathrm{nmol} / \mathrm{mmol})$} & \multicolumn{2}{|c|}{ Age (a) } \\
\hline & & & Mean & Median & Range & Mean & Median & Range & Mean & Range \\
\hline $\begin{array}{l}\mathrm{A} \\
\mathrm{B} \\
\mathrm{C}\end{array}$ & $\begin{array}{l}\text { (Odda total) } \\
\text { (Odda men) } \\
\text { (Odda women) }\end{array}$ & $\begin{array}{r}240 \\
142 \\
98\end{array}$ & $\begin{array}{l}37 \\
32 \\
43\end{array}$ & $\begin{array}{l}25 \\
22 \\
27\end{array}$ & $\begin{array}{l}2-210 \\
2-182 \\
2-210\end{array}$ & $\begin{array}{l}3.1 \\
2.6 \\
3.9\end{array}$ & $\begin{array}{l}2.1 \\
1.8 \\
2.8\end{array}$ & $\begin{array}{l}0.2-24.0 \\
0.4-16.0 \\
0.2-24.0\end{array}$ & $\begin{array}{l}28.7 \\
29.7 \\
27.2\end{array}$ & $\begin{array}{l}3-64 \\
4-64 \\
3-61\end{array}$ \\
\hline $\begin{array}{l}D \\
E \\
F\end{array}$ & $\begin{array}{l}\text { (Hadeland total) } \\
\text { (Hadeland men) } \\
\text { (Hadeland women) }\end{array}$ & $\begin{array}{r}103 \\
90 \\
13\end{array}$ & $\begin{array}{l}20 \\
19 \\
32\end{array}$ & $\begin{array}{l}13 \\
12 \\
26\end{array}$ & $\begin{array}{l}3-118 \\
3-118 \\
9-86\end{array}$ & $\begin{array}{l}1.5 \\
1.3 \\
3.3\end{array}$ & $\begin{array}{l}1.0 \\
0.9 \\
2.7\end{array}$ & $\begin{array}{l}0.3-11.6 \\
0.3-11.6 \\
1.8-7.2\end{array}$ & $\begin{array}{l}41.8 \\
43.7 \\
29.0\end{array}$ & $\begin{array}{l}16-71 \\
16-71 \\
21-52\end{array}$ \\
\hline
\end{tabular}

a Statistics (Mann-Whitney test): for $U-\mathrm{Hg}$ : $A / D$ and $E / F=p<0.001$ and $B / C=p<0.01$; for $\mathrm{Hg} / \mathrm{CR}$ : $A / D, B / C$ and $E / F=p<0.001$. 


\section{Results}

Fig 1 is a map of Odda indicating where the participants live and the position of the zinc smelter. Table 1 reveals differences in urinary mercury between the regions within Odda, the highest values occurring close to the zinc smelter and the lowest values in the center of Odda. The sex and age distribution between the different regions are of the same order.

Table 2 shows that the urinary mercury was higher in Odda than in Hadeland. Women had a higher urinary mercury level than men in both regions. Fig 2 and 3 show that the sex-dependent differences were negligible before the age of $15 \mathrm{a}$ and after the age of $45 \mathrm{a}$. The figures also reveal a reduction of the urinary mercury with advancing age.

Table 3 shows that, within the family group, the mothers had a significantly higher urinary mercury level than the fathers. A positive correlation of the unadjusted and creatinine-adjusted urinary mercury levels of the fathers with the corresponding values of their family members was also found (table 4).

Fig 4 and 5 give the cumulative distribution of unadjusted and creatinineadjusted urinary mercury for all the subjects from Odda and Hadeland. Without creatinine-adjustment the 95 percentile was found to be $105 \mathrm{nmol}$ of mercury/l of urine, and with creatinine adjustment it was $7.6 \mathrm{nmol}$ of mercury $/ \mathrm{mmol}$ of creatinine. The respective median values were $22 \mathrm{nmol} / \mathrm{l}$ and $1.8 \mathrm{nmol} / \mathrm{mmol}$. The corresponding mean values were computed to be $32 \mathrm{nmol}$ of mercury/1 of urine and $2.6 \mathrm{nmol}$ of mercury/mmol of creatinine.

\section{Discussion}

The study revealed geographic differences between Odda and Hadeland and within Odda. The Hadeland group worked in a glass production plant with exposure to a hot environment. Mercury excretion

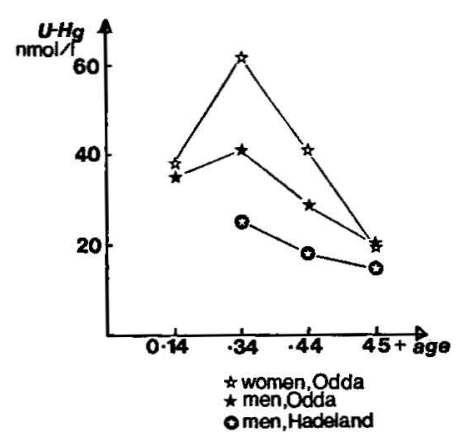

Fig 2. Unadjusted urinary mercury $(\mathrm{U}-\mathrm{Hg})$ in relation to age, sex, and geographic region. The women from Hadeland have been omitted because the group was too small and the age distribution too narrow.

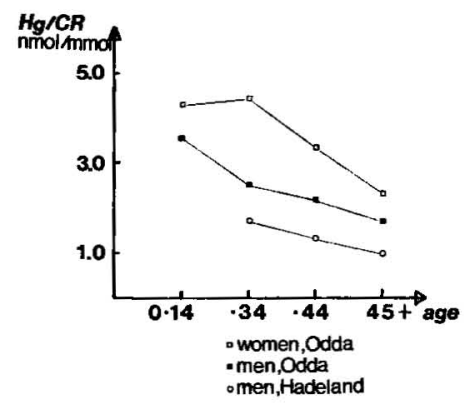

Fig 3. Creatinine-adjusted urinary mercury $(\mathrm{Hg} / \mathrm{CR})$ in relation to age, sex and geographic region. See fig 2 also.

Table 3. Unadjusted $(\mathrm{U}-\mathrm{Hg})$ and creatinine-adjusted $(\mathrm{Hg} / \mathrm{CR})$ urinary mercury among 31 families living close to a zinc smelter.a

\begin{tabular}{|c|c|c|c|c|c|c|c|c|c|}
\hline & \multirow{2}{*}{ Number } & \multicolumn{3}{|c|}{$\mathrm{U}-\mathrm{Hg}(\mathrm{nmol} / \mathrm{l})$} & \multicolumn{3}{|c|}{$\mathrm{Hg} / \mathrm{CR}(\mathrm{nmol} / \mathrm{mmol})$} & \multicolumn{2}{|c|}{ Age (a) } \\
\hline & & Mean & Median & Range & Mean & Median & Range & Mean & Range \\
\hline $\begin{array}{l}\text { Fathers } \\
\text { Mothers } \\
\text { Boy children } \\
\text { Girl children }\end{array}$ & $\begin{array}{l}31 \\
30 \\
32 \\
20\end{array}$ & $\begin{array}{l}30 \\
55 \\
45 \\
53\end{array}$ & $\begin{array}{l}22 \\
37 \\
25 \\
34\end{array}$ & $\begin{array}{l}9-103 \\
9-198 \\
4-182 \\
8-210\end{array}$ & $\begin{array}{l}2.3 \\
4.5 \\
4.0 \\
6.0\end{array}$ & $\begin{array}{l}1.6 \\
3.9 \\
2.3 \\
3.8\end{array}$ & $\begin{array}{l}0.6-7.2 \\
0.2-11.0 \\
0.6-16.0 \\
1.1-24.0\end{array}$ & $\begin{array}{r}38.2 \\
34.6 \\
11.5 \\
9.5\end{array}$ & $\begin{array}{r}29-63 \\
19-55 \\
5-24 \\
4-21\end{array}$ \\
\hline
\end{tabular}

a Statistics (Mann-Whitney test): U-Hg for father/mother $=\mathrm{p}<0.05, \mathrm{Hg} / \mathrm{CR}$ for father/mother $=$ $p<0.001$. 
through sweat may have been of importance. Sauna therapy for mercury poisoning is described in the literature (9). The differences within the Odda region, however, strongly suggest that the differences in urinary mercury were caused by mercury output from the zinc smelter.

In a previous study of dentists and dental assistants we found that women have a significantly higher urinary mer-

Table 4. Urinary mercury among 31 families living close to a zinc smelter a The unadjusted $(\mathrm{U}-\mathrm{Hg})$ and creatinine-adjusted $(\mathrm{Hg} / \mathrm{CR})$ urinary mercury values of the fathers have been correlated to the corresponding values of their family members.

\begin{tabular}{lccc}
\hline & & \multicolumn{2}{c}{ Correlation } \\
& $\mathrm{Na}$ & $\begin{array}{c}\text { coefficient } \\
\text { (Pearson), R }\end{array}$ & $\mathrm{p}$-Value \\
\cline { 2 - 4 } $\mathrm{U}-\mathrm{Hg}$ & 82 & 0.37 & 0.001 \\
$\mathrm{Hg} / \mathrm{CR}$ & 82 & 0.40 & 0.001 \\
\hline
\end{tabular}

a $\mathbf{N}=$ number of persons in the analysis. The fathers' own values have been omitted because they were used as a correlate for the father's own family members.

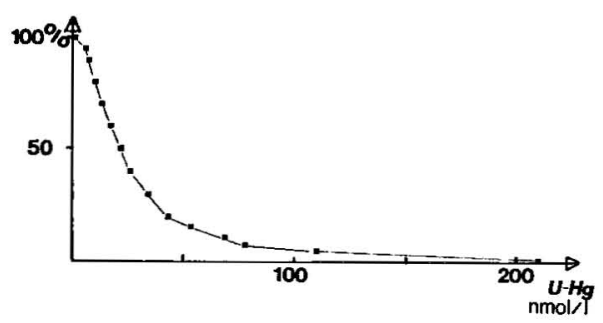

Fig 4. Unadjusted urinary mercury $(\mathrm{U}-\mathrm{Hg})-$ Cumulative frequency distribution of the total material $(\mathrm{N}=343)$.

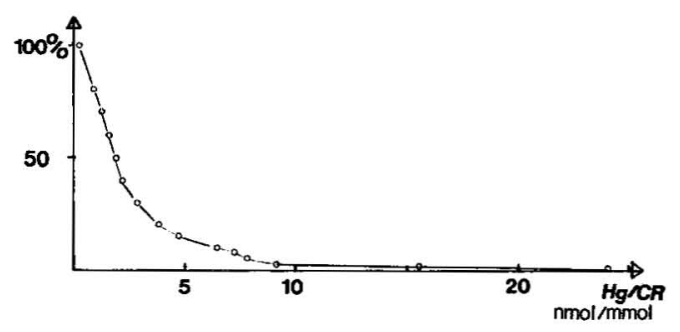

Fig 5. Creatinine-adjusted urinary mercury (Hg/CR) - Cumulative frequency distribution of the total material $(\mathrm{N}=343)$. cury level than men (5). Shimomura et al (8) showed that the mercury in hair is higher among men than women and that the difference starts at puberty (8). Fig 2 and 3 in this study also indicate that the sex-dependent difference starts at puberty and ends at menopause, a result suggesting that the difference may be hormonally determined. The mechanism for such a difference is not known.

With respect to urinary mercury we have previously reported age differences similar to those found in the present study. The mechanism for this difference is unknown. The reduction in the glomerular filtration rate that takes place with advancing age may therefore explain the differences we have found, but it is not clear whether the glomerular filtration rate is of any importance to mercury excretion (2).

The good agreement of urinary mercury found between members of the same family (table 4) suggests that dietary factors may be of importance since members of the same family generally eat the same type of food. The positive correlation may, however, also be explained by geographic differences in urinary mercury between the regions close to the zinc smelter. The difference in urinary mercury between fathers and mothers within the family group strongly suggests that the sex differences found in this study cannot be explained by external factors such as diet or place of living.

The Institute of Occupational Health in Oslo has, up to now, regarded $100 \mathrm{nmol}$ of mercury/ 1 of urine and $10 \mathrm{nmol}$ of mercury/mmol of creatinine as upper limits in a Norwegian reference population without occupational exposure to mercury. These values correspond to the 94 percentile and the 98 percentile of this study, respective$l y$, and therefore the present study supports existing reference values. When using these limits in the surveillance of mercury-exposed workers, one should, however, bear in mind sex, age and geographic differences.

\section{References}

1. Ebbestad U, Gundersen N, Torgrimsen $T$. A simple method for the determination of inorganic mercury and methylmercury in 
biological samples by flameless atomic absorption. At absorpt newsl 14 (1975) 142144.

2. Friberg L, Vostal J. Mercury in the environment. The Karolinska Institute, Stockholm 1971.

3. Goldwater LJ. Occupational exposure to mercury. J r inst public health 27 (1964) $279-285$.

4. Gundersen N, Lie A. Kvikksølveksponering ved dentallaboratorier [Mercury exposure in dental laboratories]. Institute of Occupational Health, Oslo 1980. (Report HD 851/801215).

5. Gundersen N, Lie A. Kvikksølveksponering ved tannlelekontorer [Mercury exposure in dental offices]. Nor tannlaegeforen tid 91 (1981) 219-266.

6. Molyneux MKB. Observation of the excretion rate and concentration of mercury in the urine. Ann occup hyg 9 (1966) 95-102.

7. Piotrowsky JK, Trojanowska BP, Mogilnicka EM. Excretion kinetics and variability of urinary mercury in workers exposed to mercury vapors. Int arch environ health 35 (1975) 245-246.

8. Shimomura S, Kimura A, Nakagawa $H$, Takao M. Mercury levels in human hair and sex factors. Environ res 22 (1980) $22-30$.

9. Stopford W. Industrial exposure to mercury. In: Nriagu JO, ed. The biogeochemistry of mercury in the environment.
Elsevier/North-Holland Biomedical Press, Amsterdam 1979, pp 367-398

10. Taylor A, Marks V. Measurements of urinary mercury excretion by atomic absorption in health and disease. $\mathrm{Br} \mathrm{j}$ ind med 30 (1973) 293-296.

11. Valkonen S, Kivistö H, Aitio A. Lysosomal enzyme activities and diurnal variation of urinary excretion in workers exposed to mercury vapors. In: Bye $E$, Gjølstad $M$, Gundersen $\mathrm{N}$, ed. 29. Nordic conference of occupational hygiene, Norway, Nov. 1980. Institute of Occupational Health, Oslo 1980 , pp 37-38. (Report HD 842/80). Abstract.

12. Vokac S, Gundersen N, Magnus P, Jebens E, Bakka T. Circadian rhythmicity of the urinary excretion of mercury, potassium and catecholamines in unconventional shift-work systems. Scand j work environ health 6 (1980) 188-196.

13. Watson WD. Economic considerations in controlling mercury pollution. In: Nriagu JO, ed. The biogeochemistry of mercury in the environment. Elsevier/North-HoIland Biomedical Press, Amsterdam 1979, pp $41-78$.

14. World Health Organization. Recommended health-based limits in occupational exposure to heavy metals. Geneva 1980 .

Received for publication: 16 November 1981 